\title{
Reproductive cycle and sexual maturation of the musky octopus Eledone moschata (Cephalopoda: Octopodidae) in the northern and central Adriatic Sea
}

\author{
SVJETLANA KRSTULOVIĆ ŠIFNER and NEDO VRGOČ \\ Institute of Oceanography and Fisheries Split, Šetalište Ivana Meštrovića 63, 21000 Split, Croatia. E-mail: sifner@izor.hr
}

\begin{abstract}
SUMMARY: Length-weight relationships, sex ratio, maturity patterns, reproductive outputs, fecundity and spawning period of the musky octopus Eledone moschata (Lamarck, 1798) in the northern and central Adriatic Sea are presented for the first time. Samples were collected on a monthly basis by commercial bottom trawls between October 2001 and June 2003. A total of 1552 specimens were analysed (779 males, 764 females, 9 undetermined). The overall sex ratio was close to 1:1, but during summer males were dominant. Length-weight relationships calculated for each sex and the whole sample showed negative allometric growth $(b<3)$. The allometric coefficient in maturing and mature individuals revealed isometric growth $(b=3)$. The length at 50\% maturity showed that males mature at smaller sizes than females. The mean total fecundity was $310 \pm 60$, with a mean oocyte length and width of $9.39 \pm 1.99 \mathrm{~mm}$ and $2.57 \pm 0.72 \mathrm{~mm}$ respectively. The number of spermatophores ranged from 45 to 287 with a mean length of $17.71 \pm 3.27 \mathrm{~mm}$. The maturity indices used to analyse the maturation process showed that the pattern of seasonal change had the lowest values in summer for both sexes. The results indicate that in the Adriatic Sea E. moschata has an extended reproductive season that starts in autumn and ends in spring, with spawning peaks between January and April.
\end{abstract}

Keywords: Eledone moschata, reproductive biology, fecundity, Adriatic Sea.

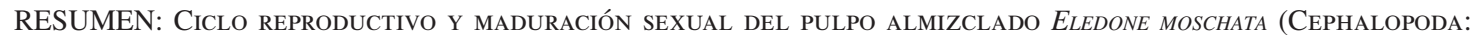
OCTOPODIDAE) EN EL MAR ADRIÁtiCO NORTEÑO Y CENTRAL. - En este documento se presentan por primera vez la relación talla-peso, proporción de los sexos, patrones de madurez, productos reproductivos, fecundidad y el periodo de desove del pulpo almizclado, Eledone moschata (Lamarck, 1798), en el Mar Adriático central y norte. Las muestras fueron recolectadas mensualmente en base a una red de muestreo de arrastre comercial entre octubre de 2001 y junio de 2003. Se analizaron un total de 1552 muestras (779 machos, 764 hembras y 9 indeterminados). La proporción sexual de la muestra total fue cercana a 1:1, pero el número de machos fue dominante durante el verano. La relación talla-peso por sexos y total de la muestra mostró un crecimiento alométrico negativo $(b<3)$. El coeficiente de alometría en ambos sexos reveló un crecimiento isométrico $(b=3)$ en la maduración y en individuos maduros. La talla de primera madurez sexual mostró que los machos maduran a tallas menores que las hembras. La fecundidad media total fue de $310 \pm 60$ ovocitos, con talla y anchura media de los mismos de $9.39 \pm 1.99 \mathrm{~mm}$ y $2.57 \pm 0.72 \mathrm{~mm}$, respectivamente. El número de espermatóforos en los machos varió entre el 45 y el 287 y su longitud promedio de $17.71 \pm 3.27 \mathrm{~mm}$. Los índices de madurez utilizados para analizar el proceso de maduración mostraron una variación estacional con valores más bajos en el verano en ambos sexos. Los resultados indican que en el mar Adriático E. moschata tiene una época reproductiva larga, que comienza en otoño y termina en primavera, con picos de desove entre los meses de enero y abril.

Palabras clave: Eledone moschata, biología reproductiva, fecundidad, mar Adriático.

\section{INTRODUCTION}

The musky octopus, Eledone moschata (Lamarck, 1798) (Cephalopoda: Octopodidae) inhabits the en- tire Mediterranean and the Gulf of Cádiz in the eastern Atlantic (Roper et al., 1984). It is widely distributed on the continental shelf, and is most abundant at depths down to $100 \mathrm{~m}$. The musky octopus is a com- 
mercially important species for the Mediterranean demersal fishery, and is mainly caught by bottom trawl nets (Belcari and Sbrana, 1999). The distribution and abundance of the species has been studied in several areas of the Mediterranean (Lefkaditou et al., 1998, 2001; Pipitone et al., 2000; Quetglas et al., 2000; Salman et al., 2000; Belcari et al., 2002). The biological characteristics of populations from the Catalan Sea (Mangold-Wirz, 1963; Mangold, 1983), the Gulf of Gabes (Ezzeddine-Najai, 1997), the Gulf of Cádiz (Silva et al., 2004) and the Aegean Sea (Önsoy and Salman, 2004; Akyol et al., 2007) have been described. Observations on the biology of the species bred in captivity have also been reported (Mangold-Wirz and Boucher-Rodoni, 1973; Boletzky, 1975; Şen, 2007). There are several studies on the distribution and abundance of this species in the Adriatic Sea (Piccinetti and Jukić, 1988; Casali et al., 1998; Krstulović Šifner et al., 2004, 2005), but there are few references to the reproductive biology of $E$. moschata in the area (Manfrin-Piccinetti and Rizzoli, 1984; Soro and Piccinetti-Manfrin, 1989). The aim of the present paper was to fulfil the existing gap in biological studies and provide information on the reproductive biology of E. moschata in the northern and central Adriatic Sea. The first detailed data on the sex ratio, length-weight relationships, maturity patterns, reproductive outputs, fecundity and spawning period in the area are presented.

\section{MATERIALS AND METHODS}

A total of 1552 specimens of E. moschata with mantle lengths between 32 and $140 \mathrm{~mm}$, and body weights from 8.0 to $629.8 \mathrm{~g}$ were examined. Samples were caught monthly by commercial bottom trawlers operating on the continental shelf on the eastern side of the northern and central Adriatic Sea, between October 2001 and June 2003 (Fig. 1). The mantle length (ML) and body weight (BW) of animals defrosted at room temperature were measured to the nearest $1 \mathrm{~mm}$ and $0.1 \mathrm{~g}$ respectively. Sex and maturity stages for males were recorded using the gonad maturity scale proposed by Ezzeddine-Najai (1997):

I - immature: testis very small; vas deferens not visible; Needham's sac transparent and empty;

II - maturation: testis small, whitish; vas deferens visible; Needham's sac with several transparent spermatophores;

III - mature: testis voluminous; vas deferens enlarged, creamy-white; Needham's sac developed and filled with spematophores;

IV - spent: testis flaccid; Needham's sac without any or with disintegrating spermatophores.

Maturity stages of females were defined using the modified scale of Ezzeddine-Najai (1997) with five stages, based on the state of the reproductive organs and appearance and length of the oocytes (Krstulović Šifner, 2004):

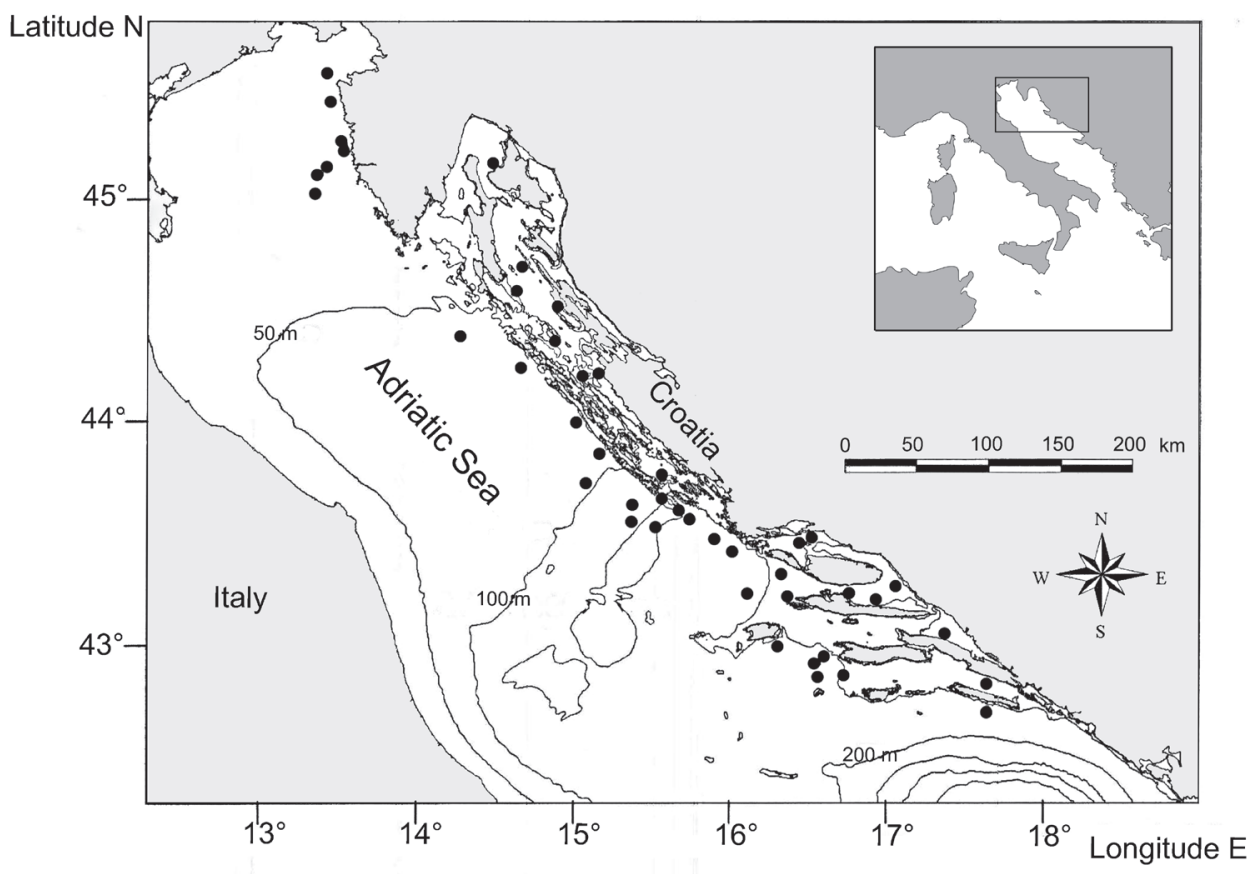

FIG. 1. - Northern and central Adriatic Sea; the black dots indicate the sampling stations for E. moschata on the eastern side of the area 
I - immature: oviducts and oviductal glands visible, very small, not developed; ovary visible, small and whitish; oocytes small (major axis less than 5.5 $\mathrm{mm}$ ), whitish to pale yellow, surface smooth;

II - early maturation: oviducts and oviductal glands visible, but still whitish; ovary occupying a small portion of the mantle cavity; oocytes larger (major axis between 5.5 and $8.5 \mathrm{~mm}$ ), pale yellow, longitudinally striated;

III - advanced maturation: oviducts of beige to pale pinkish colour, oviductal glands large, ovary occupying large portion of the mantle cavity; oocytes yellow and large with striated surface (major axis between 8.5 and $12.5 \mathrm{~mm}$ );

IV - mature: oviducts completely developed, oviductal glands very large and beige to pale brown in colour; ovary very large, occupying whole posterior half of the mantle cavity; oocytes very large, dark yellow, with longitudinally striated or smooth surface (longer than $12.5 \mathrm{~mm}$ in major axis).

V - spent: ovary less voluminous; no large oocytes.

Spent stages were not recorded in this study. The maturity stage III in males and maturity stages III and IV in females were used to calculate the size at $50 \%$ maturity and proportion of mature individuals by month. Gonad weight (GW), oviductal complex weight $(\mathrm{OCW})$ and spermatophoric complex weight (SCW) were also recorded. The total weight of the reproductive organs, called genital complex weight (GCW), was related to the total body weight for both sexes (Boyle and Daly, 2000).

The sex ratio was calculated monthly, seasonally and annually, and deviations from the expected 1:1 ratio were tested with the Chi-square $\left(\chi^{2}\right)$ test. Length-weight relationships were estimated for the whole sample, for males and females, seasonally and according to the maturity stage, using the following equation: $B W=a M L^{b}$. Parameters $a$ and $b$ were calculated using ordinary least squares regressions, after transforming the data into natural logarithms. The length-somatic weight relationships by sex and maturity stage were also computed to determine the extent to which the length-weight relationship was affected by the relative growth in the reproductive organs. An analysis of covariance (ANCOVA) was used to test the differences between the slopes obtained for males and females. A Student's $t$-test was used to evaluate relative growth isometry and to test differences between subsequent maturity stages.
The mantle length at 50\% maturity (ML50\%) was estimated using the non-linear least squares method after fitting the relative length-frequency distribution for length classes of mature individuals to a logistic curve with the formula:

$$
\mathrm{P}=1 / 1+\exp [-b(M L-M L 50 \%)]\}
$$

where $P$ is the relative frequency of mature individuals per length class and $b$ is the slope parameter of the maturity curve.

Reproduction peaks were estimated by analysing monthly changes in the values of the maturity indices and in the proportions of the advanced maturity stages throughout the year. Indices of reproductive status for males and females were calculated using the following expressions:

(i) Gonadosomatic index: $G S I=(G W / B W) \times 100$;

(ii) Spermatophoric complex index for males:

$S C I=S C W / B W \times 100$ and oviductal complex index for females: $O C I=(O C W / B W) \times 100$

(iii) Maturity coefficient for males:

$M C O=(G W+S C W) \times 100 /[B W-(G W+S C W)]$ and for females:

$M C O=(G W+O C W) \times 100 /[B W-(G W+O C W)]$.

Gonads of 65 mature females were stored in $4 \%$ formaldehyde, and oocytes were subsequently examined, counted, and measured along the longest and shortest diameters using a stereo light-microscope with a micrometer. Spermatophores from 206 mature males were also counted and measured with electronic digital vernier calipers to the nearest $0.01 \mathrm{~mm}$. Potential fecundity (PF) was calculated as the total number of oocytes of all sizes present in the ovary (Laptikhovsky, 1999). Relative fecundity (RF) was estimated as the ratio of PF to BW.

\section{RESULTS}

\section{Sex ratio}

A total of 779 males, 764 females and 9 individuals of undetermined sex was analysed. The mantle lengths ranged between 34 and $118 \mathrm{~mm}$ in males, and between 32 and $140 \mathrm{~mm}$ in females (Fig. 2). The mean mantle length was $75.2 \pm 17.47 \mathrm{~mm}$ and $75.7 \pm 18.60 \mathrm{~mm}$ for males and females respectively. The overall sex ratio $(\mathrm{m} / \mathrm{f})$ was 1.02:1. Females 


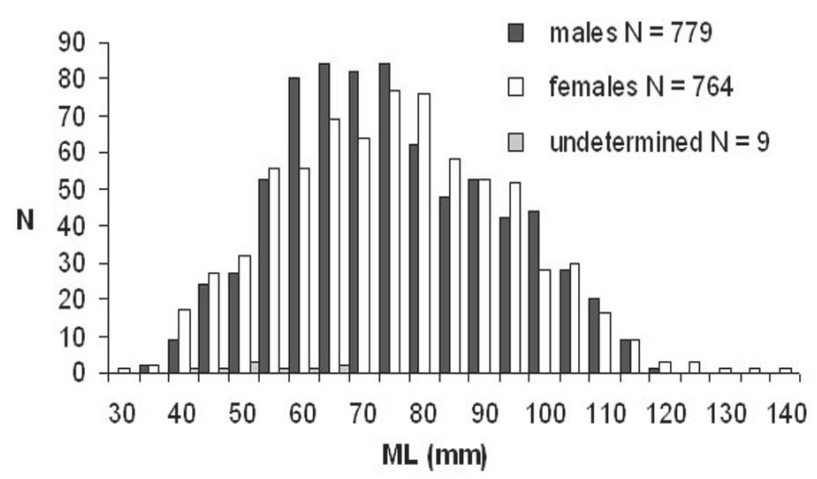

FIG. 2. - Length-frequency distribution of males, females and undetermined individuals of $E$. moschata from the eastern side of the northern and central Adriatic Sea

dominated significantly in October $\left(\chi^{2}=4.02\right)$, while males outnumbered females in August $\left(\chi^{2}=8.00\right)$ and September $\left(\chi^{2}=16.49\right)(P<0.05)$. In the rest of the year the $\mathrm{m} / \mathrm{f}$ ratio was close to $1: 1$ (Table 1 ). When compared by season, it was evident that males dominated significantly in summer $\left(\chi^{2}=23.48 ; P<0.05\right)$. The number of males and females in each length class was not significantly different $(P>0.05)$.

\section{Length-weight relationships}

The overall length-total weight relationship of the studied population of E. moschata in the Adriatic Sea can be described by the following expression:
TABLE 1. - Sex ratio of E. moschata from the eastern side of the northern and central Adriatic Sea by month, season and the total sample (*-significant difference $\left(\chi^{2}\right.$ test, $\left.P<0.05\right)$ ): Nm, number of males; Nf, number of females; Nt, total number of males and females; \% m, percentage of males $(\mathrm{Nm} / \mathrm{Ntx} 100)$; \% , percentage of females (Nf/Ntx100); m/f, male/female ratio

\begin{tabular}{lrrrrrrr}
\hline Month/season & $\mathrm{Nm}$ & $\mathrm{Nf}$ & $\mathrm{Nt}$ & $\% \mathrm{~m}$ & $\% \mathrm{f}$ & $\mathrm{m} / \mathrm{f}$ & $\chi^{2}$ \\
\hline January & 42 & 39 & 81 & 51.85 & 48.15 & 1.08 & 0.11 \\
February & 44 & 53 & 97 & 45.36 & 54.64 & 0.83 & 0.84 \\
March & 51 & 65 & 116 & 43.97 & 56.03 & 0.78 & 1.69 \\
April & 70 & 64 & 134 & 52.24 & 47.76 & 1.09 & 0.27 \\
May & 47 & 68 & 115 & 40.87 & 59.13 & 0.69 & 3.83 \\
June & 65 & 53 & 118 & 55.08 & 44.92 & 1.23 & 1.22 \\
July & 53 & 38 & 91 & 58.24 & 41.76 & 1.39 & 2.47 \\
August & 48 & 24 & 72 & 66.67 & 33.33 & 2.00 & $8.00 *$ \\
September & 60 & 23 & 83 & 72.29 & 27.71 & 2.61 & $16.49 *$ \\
October & 97 & 127 & 224 & 43.30 & 56.70 & 0.76 & $4.02^{*}$ \\
November & 140 & 129 & 269 & 52.04 & 47.96 & 1.09 & 0.45 \\
December & 62 & 81 & 143 & 43.36 & 56.64 & 0.77 & 2.52 \\
Spring & 182 & 185 & 367 & 49.59 & 50.41 & 0.98 & 0.02 \\
Summer & 161 & 85 & 246 & 65.45 & 34.55 & 1.89 & $23.48 *$ \\
Autumn & 299 & 337 & 636 & 47.01 & 52.99 & 0.89 & 2.27 \\
Winter & 137 & 157 & 294 & 46.60 & 53.40 & 0.87 & 1.36 \\
& & & & & & & \\
Total & 779 & 764 & 1543 & 50.49 & 49.51 & 1.02 & 0.15 \\
& & & & & & & \\
\hline
\end{tabular}

$$
B W=0.001 \times M L^{2.7152}(\mathrm{r}=0.9536)
$$

The value of the $b$ coefficient $(<3)$ indicates that this species shows overall negative allometric growth. The same results were obtained when males and females were analysed separately (Table 2). There was no significant difference when the slopes of the

TABLE 2. - Length-total weight relationships of E. moschata from the eastern side of the northern and central Adriatic Sea by sex in the total sample and by season and maturity stage (immature and maturing/mature): N, number of individuals; ML, mean mantle length; SD, standard deviation; r, correlation coefficient; $a$ and $b$, parameters; $\mathrm{S}$, significance level of $b$ compared to $3(* P<0.05, * * P<0.01$, ns, not significant)

\begin{tabular}{|c|c|c|c|c|c|c|c|c|c|c|}
\hline & Sex & $\mathrm{N}$ & $\begin{array}{c}\mathrm{ML} \\
\text { range }(\mathrm{mm})\end{array}$ & $\mathrm{ML} \pm \mathrm{SD}$ & $\begin{array}{c}\mathrm{BW} \\
\text { range }(\mathrm{g})\end{array}$ & $\mathrm{BW} \pm \mathrm{SD}$ & $\mathrm{r}$ & $\mathrm{a}$ & $\mathrm{b}$ & $\mathrm{S}$ \\
\hline Total & $\begin{array}{l}\mathrm{M} \\
\mathrm{F}\end{array}$ & $\begin{array}{l}779 \\
764\end{array}$ & $\begin{array}{l}34-118 \\
32-140\end{array}$ & $\begin{array}{l}73.10 \pm 17.8 \\
74.00 \pm 18.5\end{array}$ & $\begin{array}{r}8.04-554.20 \\
10.15-629.81\end{array}$ & $\begin{array}{l}144.55 \pm 100.6 \\
140.87 \pm 91.5\end{array}$ & $\begin{array}{l}0.950 \\
0.958\end{array}$ & $\begin{array}{l}0.0009 \\
0.0013\end{array}$ & $\begin{array}{l}2.7656 \\
2.6644\end{array}$ & $\begin{array}{l}* \\
* *\end{array}$ \\
\hline Spring & $\begin{array}{l}\mathrm{M} \\
\mathrm{F}\end{array}$ & $\begin{array}{l}182 \\
185\end{array}$ & $\begin{array}{l}36-118 \\
32-140\end{array}$ & $\begin{array}{l}83.83 \pm 21.9 \\
81.55 \pm 25.2\end{array}$ & $\begin{array}{l}16.82-554.20 \\
16.93-629.81\end{array}$ & $\begin{array}{l}200.87 \pm 128.0 \\
173.43 \pm 117.6\end{array}$ & $\begin{array}{l}0.943 \\
0.969\end{array}$ & $\begin{array}{l}0.0011 \\
0.0037\end{array}$ & $\begin{array}{l}2.6889 \\
2.4040\end{array}$ & $\begin{array}{l}* * \\
* *\end{array}$ \\
\hline Summer & $\begin{array}{l}\mathrm{M} \\
\mathrm{F}\end{array}$ & $\begin{array}{c}161 \\
85\end{array}$ & $\begin{array}{l}34-61 \\
32-61\end{array}$ & $\begin{array}{l}54.23 \pm 6.5 \\
53.49 \pm 5.9\end{array}$ & $\begin{array}{r}8.04-108.00 \\
10.15-141.25\end{array}$ & $\begin{array}{l}55.52 \pm 19.1 \\
54.76 \pm 21.6\end{array}$ & $\begin{array}{l}0.871 \\
0.706\end{array}$ & $\begin{array}{l}0.0040 \\
0.0053\end{array}$ & $\begin{array}{l}2.3772 \\
2.3093\end{array}$ & $\begin{array}{l}* * \\
* *\end{array}$ \\
\hline Autumn & $\begin{array}{l}\mathrm{M} \\
\mathrm{F}\end{array}$ & $\begin{array}{l}299 \\
337\end{array}$ & $\begin{array}{l}50-113 \\
50-114\end{array}$ & $\begin{array}{l}72.91 \pm 9.0 \\
71.41 \pm 8.5\end{array}$ & $\begin{array}{l}41.69-526.40 \\
41.54-376.91\end{array}$ & $\begin{array}{l}125.01 \pm 62.7 \\
115.32 \pm 50.0\end{array}$ & $\begin{array}{l}0.796 \\
0.782\end{array}$ & $\begin{array}{l}0.0007 \\
0.0025\end{array}$ & $\begin{array}{l}2.7937 \\
2.4991\end{array}$ & $\begin{array}{l}* \\
* *\end{array}$ \\
\hline Winter & $\begin{array}{l}\mathrm{M} \\
\mathrm{F}\end{array}$ & $\begin{array}{l}137 \\
157\end{array}$ & $\begin{array}{l}45-117 \\
45-118\end{array}$ & $\begin{array}{l}88.04 \pm 10.3 \\
87.92 \pm 8.7\end{array}$ & $\begin{array}{l}28.06-545.62 \\
32.08-532.56\end{array}$ & $\begin{array}{l}219.42 \pm 102.5 \\
206.95 \pm 80.3\end{array}$ & $\begin{array}{l}0.863 \\
0.832\end{array}$ & $\begin{array}{l}0.0001 \\
0.0002\end{array}$ & $\begin{array}{l}3.3451 \\
3.0493\end{array}$ & $\begin{array}{l}* * \\
\mathrm{~ns}\end{array}$ \\
\hline Immature & $\begin{array}{l}\mathrm{M} \\
\mathrm{F}\end{array}$ & $\begin{array}{l}478 \\
526\end{array}$ & $\begin{array}{l}34-110 \\
32-111\end{array}$ & $\begin{array}{l}65.19 \pm 15.4 \\
64.08 \pm 14.8\end{array}$ & $\begin{array}{r}8.04-353.31 \\
10.15-232.40\end{array}$ & $\begin{array}{l}79.25 \pm 57.1 \\
79.69 \pm 50.4\end{array}$ & $\begin{array}{l}0.953 \\
0.937\end{array}$ & $\begin{array}{l}0.0018 \\
0.0019\end{array}$ & $\begin{array}{l}2.5617 \\
2.5599\end{array}$ & $\begin{array}{l}* * \\
* *\end{array}$ \\
\hline $\begin{array}{l}\text { Maturing/ } \\
\text { Mature }\end{array}$ & $\begin{array}{l}\mathrm{M} \\
\mathrm{F}\end{array}$ & $\begin{array}{l}301 \\
238\end{array}$ & $57-118$ & $\begin{array}{l}88.54 \pm 15.1 \\
92.07 \pm 16.4\end{array}$ & $52.3-554.20$ & $\begin{array}{l}267.37 \pm 115.7 \\
278.18 \pm 108.3\end{array}$ & 0.944 & 0.0003 & 2.9969 & ns \\
\hline
\end{tabular}


TABLE 3. - Length-somatic weight relationships of E. moschata from the eastern side of the northern and central Adriatic Sea by sex and maturity stage: $\mathrm{r}$, correlation coefficient; $a$ and $b$, parameters; $\mathrm{s}$, significance level of $b$ compared to 3 ( $* P<0.05$, ** $P<0.01$, ns, not significant)

\begin{tabular}{lccccc}
\hline & Sex & $\mathrm{r}$ & $\mathrm{a}$ & $\mathrm{b}$ & $\mathrm{s}$ \\
\hline Total & $\mathrm{M}$ & 0.917 & 0.0010 & 2.7083 & $*$ \\
& $\mathrm{~F}$ & 0.927 & 0.0032 & 2.5616 & $* *$ \\
Immature & $\mathrm{M}$ & 0.875 & 0.0025 & 2.5500 & $* *$ \\
& $\mathrm{~F}$ & 0.884 & 0.0040 & 2.4879 & $* *$ \\
Maturing/ & $\mathrm{M}$ & 0.831 & 0.0071 & 2.9676 & $\mathrm{~ns}$ \\
Mature & $\mathrm{F}$ & 0.870 & 0.0084 & 2.8290 & $*$ \\
& & & & & \\
\hline
\end{tabular}

power formula were compared between the two sexes (ANCOVA, $F_{1,1540}=2.170, P=0.141$ ). The highest values of $b$ were obtained in winter: 3.3451 and 3.0493 for males and females respectively (Table 2). In all other seasons the coefficient $b$ was significantly lower than 3. In immature individuals $b$ values were significantly lower than 3 for males and females, while maturing and mature specimens of both sexes showed isometric growth (b 3) (Table 2). Lengthsomatic weight relationships in females showed negative allometric growth for the total sample, and also for immature and maturing/mature individuals. For males in the mature/maturing category, the LSW relationships showed isometric growth (Table $3)$. When slopes were compared with the respective values of length-total weight relationships, a significant difference was observed in females (ANCOVA, $\left.F_{1,473}=6.343, P=0.004\right)$ and a faster relative growth in the reproductive organs as a consequence of the maturation process; while for maturing/mature males no significant difference in the slopes was found (ANCOVA, $F_{1,599}=1.501, P=0.192$ ).

\section{Maturity stages and spawning season}

In the total sample $67 \%$ of males and $72 \%$ of females were immature (I), and this category was
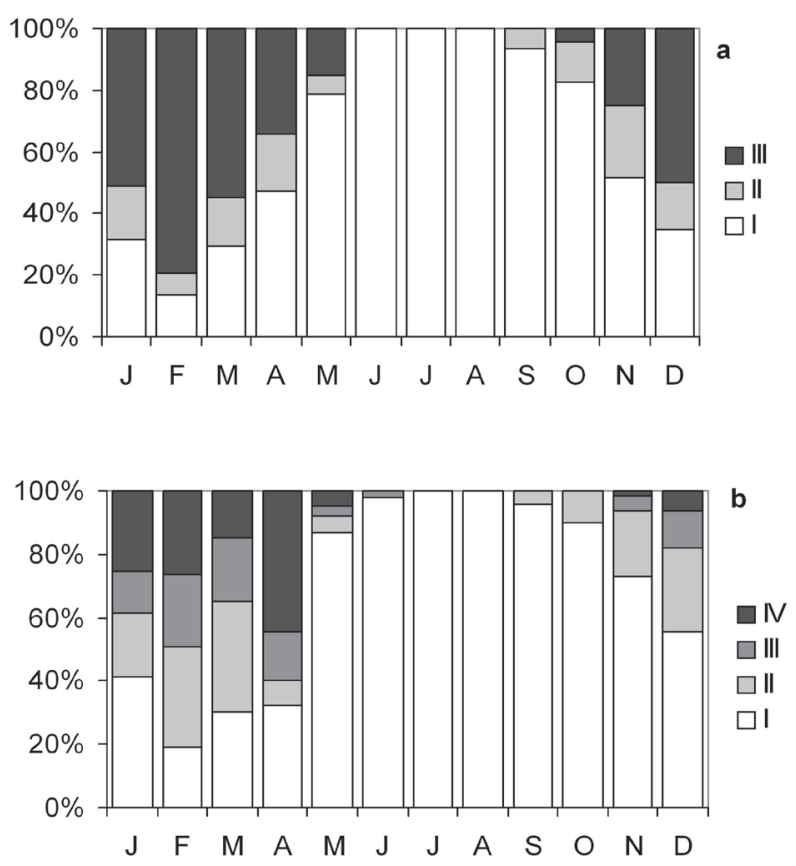

FIG. 3. - Percentage (\%) of maturity stages by month for: a) males and b) females of $E$. moschata from the eastern side of the northern and central Adriatic Sea

present with the highest percentage during summer for both sexes (Fig. 3). Maturation occurred in autumn, and was abrupt in males and much slower in females. Therefore, by the end of autumn (December) the proportion of mature males was high $(50.0 \%)$ and still relatively low in females $(18.0 \%)$. The highest percentage of mature individuals of both sexes was recorded between January and April, indicating that the most intensive reproductive activity occurs in winter and early spring. The highest values were recorded in February (79.6\%) and April $(60.0 \%)$ for males and females respectively. Significant differences were observed between the mean length of individuals in subsequent maturity stages $(P<0.05)$, except for females in maturity stages III and IV $(P>0.05)$ (Table 4).

TABLE 4. - Mantle length range (mm) and mean mantle length with standard deviation (ML \pm SD) by maturity stage (MS) for males and females of E. moschata from the eastern side of the northern and central Adriatic Sea with the results of the Student's $t$-test (*, significant difference, $P<0.05)$

\begin{tabular}{lccccccc}
\hline & \multicolumn{2}{c}{ Males } & & \multicolumn{3}{c}{ Females } \\
MS & ML range & ML \pm SD & $\mathrm{t}$ & MS & ML range & ML \pm SD & t \\
\hline I & & & & I & $32-111$ & $64.08 \pm 14.76$ & $20.56^{*}$ \\
II & $34-110$ & $65.19 \pm 15.38$ & $10.31^{*}$ & II & $66-116$ & $88.70 \pm 11.90$ & $3.68^{*}$ \\
III & $57-115$ & $81.97 \pm 14.67$ & $5.26^{*}$ & III & $72-130$ & $96.27 \pm 13.38$ & 0.48 \\
& $58-118$ & $91.09 \pm 13.55$ & & IV & $79-140$ & $97.29 \pm 12.31$ & \\
\hline
\end{tabular}



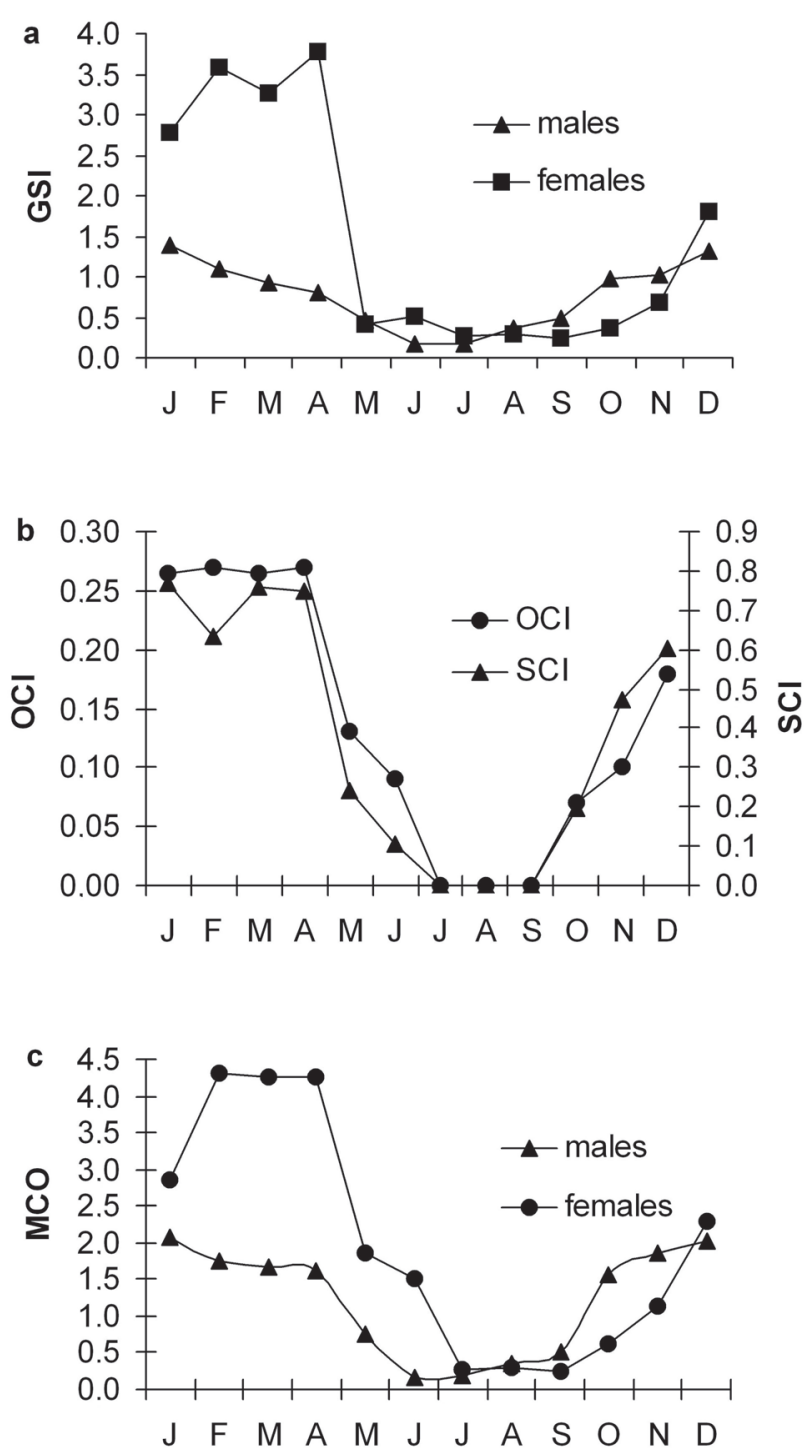

FIG. 4. - Monthly variations of: a) gonadosomatic index (GSI), b) spermatophoric complex index (SCI) and oviductal complex index (OCI), and c) maturity coefficient (MCO) for males and females of E. moschata from the eastern side of the northern and central Adriatic Sea

The highest GSI values were recorded in late autumn-winter for males and in winter-early spring for females. One peak was observed in January for males and two peaks, one in February and the other one in April, for females. A minimum was recorded in summer for both sexes (Fig. 4). The average monthly values of the maturity coefficient (MCO), spermatophoric index (SCI) and oviductal index (OCI) showed similar monthly oscillations. The lowest values for both sexes were found in summer, while the maximum was recorded in January and February for males and females respectively (Fig. 4).
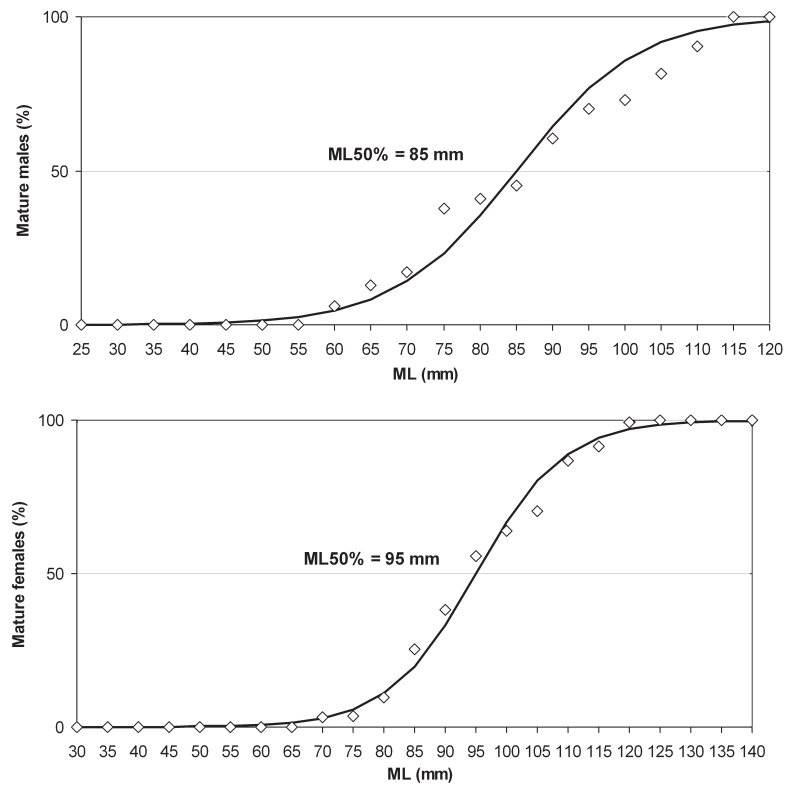

FIG. 5. - Sigmoid curves fitting the percentage of sexually mature individuals by length classes; arrows indicate ML50\% for: a) males and b) females of E. moschata from the eastern side of the northern and central Adriatic Sea

\section{Length at $50 \%$ maturity}

The mantle length at 50\% maturity (ML50\%) was $85 \mathrm{~mm}$ and $95 \mathrm{~mm}$ for males and females respectively (Fig. 5). Mean sizes at maturity for both sexes are described by the following expressions:

$$
\begin{gathered}
\text { Males: } \mathrm{P}=1 /\{1+\exp [-0.12 \times(\mathrm{ML}-85)]\} \\
(\mathrm{r}=0.9524) \\
\text { Females: } \mathrm{P}=1 /\{1+\exp [-0.14 \times(\mathrm{ML}-95)]\} \\
(\mathrm{r}=0.9751)
\end{gathered}
$$

The mantle length of mature individuals ranged between 58 and $118 \mathrm{~mm}$ in males and between 79 and $140 \mathrm{~mm}$ in females. The mean mantle length of mature individuals was $91 \mathrm{~mm}$ and $99 \mathrm{~mm}$ for males and females respectively.

\section{Reproductive outputs}

The number of spermatophores in mature males was between 45 and 287 , on average $120 \pm 60$. The length of fully developed spermatophores ranged from 9 to $23 \mathrm{~mm}$, the mean being $17.71 \pm 3.27 \mathrm{~mm}$. A positive correlation was found between the mantle length and the length of spermatophores $(\mathrm{r}=0.631$; $P<0.001)$, and between the mantle length and the number of spermatophores $(\mathrm{r}=0.379 ; P<0.001)$. 
TABLE 5. - Microsopically determined oocyte types in the ovaries of E. moschata mature females from the eastern side of the northern and central Adriatic Sea: range, mean value and standard deviation (SD) of oocyte length/width $(\mathrm{mm})$ and percentage in the ovary

\begin{tabular}{lccccc}
\hline Type of oocyte & Percentage per ovary & Length range & Mean length \pm SD & Width range & Mean width \pm SD \\
\hline Small residual & $5.42 \pm 2.63$ & $2.50-5.41$ & $3.86 \pm 0.97$ & $0.59-2.16$ & $1.32 \pm 0.36$ \\
Medium striated & $17.15 \pm 6.11$ & $5.50-8.10$ & $7.26 \pm 0.92$ & $0.61-3.50$ & $1.92 \pm 0.50$ \\
Large striated & $31.99 \pm 9.28$ & $8.11-12.45$ & $10.27 \pm 1.05$ & $1.13-4.00$ & $2.86 \pm 0.53$ \\
Very large striated & $42.21 \pm 15.37$ & $12.50-14.03$ & $13.20 \pm 0.35$ & $3.27-4.01$ & $3.59 \pm 0.16$ \\
Very large smooth & $3.23 \pm 1.56$ & $13.56-15.22$ & $14.64 \pm 0.57$ & $3.57-4.19$ & $3.85 \pm 0.15$ \\
\hline
\end{tabular}

The number of oocytes in the ovaries of mature females ranged from 210 to 459 , and the mean oocyte length and width were $9.39 \pm 1.99 \mathrm{~mm}$ and $2.57 \pm 0.72$ $\mathrm{mm}$ respectively. A positive correlation was found between oocyte length and width $(\mathrm{r}=0.840 ; P<0.001)$. On average, oocyte width was 3.8 times smaller than length $(\mathrm{Lo} / \mathrm{Wo}=3.8)$. Five oocyte types were microscopically determined (Table 5). Oocytes with a striated surface dominated in ovaries $(>90 \%)$, and their length varied between 5.50 and $14.03 \mathrm{~mm}$. Oocytes with a smooth surface, which measured from 13.56 to $15.22 \mathrm{~mm}$, on average accounted for $3.23 \%$ of the total number of oocytes in the ovary. Small, residual oocytes accounted for $5.42 \%$ of the total number present in the ovaries. The mean potential fecundity was $310 \pm 60$ oocytes per female, and the average relative fecundity was $0.95 \pm 0.14$ oocytes per gram of the total body weight. There was a positive correlation between the potential fecundity and the mantle length of mature females $(\mathrm{r}=0.758 ; P=0.003)$. The number of oocytes per gram of ovary showed a logarithmic decline with the increase in ovary weight $(\mathrm{r}=-0.702 ; P=0.016)$.

\section{Genital complex and total body weight ratio}

The comparison of the genital complex weight and the total body weight showed a positive correlation for both sexes (Fig. 6). In mature individuals

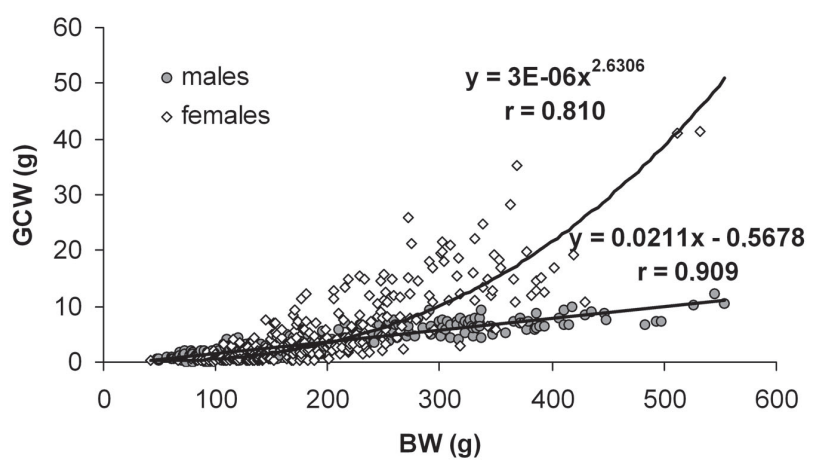

FIG. 6. - Relationship between the genital complex (GCW) and body weight (BW) for males and females of E. moschata from the eastern side of the northern and central Adriatic Sea. the weight of the genital complex accounted for up to $3.65 \%$ of the body weight in males, $18.17 \%$ in females, and $1.20 \%$ in immature individuals. The growth of the genital complex in males was isometric and linear $(\mathrm{r}=0.909 ; P<0.001)$. The curve obtained for females was power $(\mathrm{r}=0.810 ; P<0.001)$, with lower values of GCW/BW in smaller individuals, and much higher and more dispersed values of the ratio in larger individuals.

\section{DISCUSSION}

In the study area the overall sex ratio of E. moschata was close to $1: 1$ while seasonal sex ratios showed a significant dominance by males in summer. Some authors found that males dominated during the reproduction period (Mangold-Wirz, 1963; Mangold, 1983; Ezzeddine-Najai, 1997), while Silva et al. (2004) found that females dominated significantly throughout the sampling period in the Gulf of Càdiz. As in the Adriatic Sea during summer mainly E. moschata juveniles were caught (Krstulović Śifner, 2004), the domination of males is most probably a result of different behaviour patterns of juvenile males and females and the sampling limits.

The negative allometry in the length-weight relationships is in accordance with the results of other authors (Silva et al., 2004; Akyol et al., 2007). During this study an increase in weight compared to length was observed in winter, when the maturation process of $E$. moschata was very intensive in the Adriatic Sea. Furthermore, the $b$ value showed isometric growth in maturing and mature individuals, which indicates that in this phase both sexes gained more in weight than in length. The length-somatic weight relationships indicated that this increase in the allometry coefficient in maturing and mature males is mainly related to the somatic growth, while in the same category of females the reproductive system had more intensive relative growth compared to the somatic growth. 
Mantle lengths at 50\% maturity obtained for $E$. moschata were smaller compared to the results obtained by Mangold-Wirz (1963) (90 mm in males, $130 \mathrm{~mm}$ in females) and Ezzeddine-Najai (1997) (90 $\mathrm{mm}$ and $110 \mathrm{~mm}$ in males and females respectively), while Silva et al. (2004) found smaller lengths in males $(78 \mathrm{~mm})$ and larger in females $(122 \mathrm{~mm})$. Previous information on female length at maturity in the Adriatic Sea, given by Soro and Piccinetti-Manfrin (1989), is in accordance with the results of the present study.

The proportions of the different oogenetic stages of oocytes in the ovaries of mature females indicate that E. moschata probably has a group-synchronous ovulation (Rocha et al., 2001), as Önsoy and Salman (2004) previously suggested for this species. The number and sizes of oocytes are in agreement with previous results from the Adriatic Sea (Soro and Piccinetti Manfrin, 1989), the Catalan Sea (MangoldWirz, 1963) and from Atlantic Iberian waters (Silva et al., 2004). In the Aegean Sea the mean number of oocytes was much higher compared to the present study: 684 and 836 were recorded by Önsoy and Salman (2004) and Akyol et al. (2007) respectively. However, the maximum egg size was much smaller in the Aegean studies $(9.8 \mathrm{~mm}$ and $10.7 \mathrm{~mm}$ respectively). Furthermore, the same authors found a much lower average number and length of spermatophores: Önsoy and Salman (2004) noted that the mean number of spermatophores was 81 (range 14-230) and the mean length $14.1 \mathrm{~mm}$, and Akyol et al. (2007) found an average of 52 spermatophores (range 6-172) with a mean length of $13.66 \mathrm{~mm}$. These kinds of differences usually appear as a consequence of particular environmental conditions. The coastal areas of the northern and central Adriatic, where the bulk of the population is distributed, are biologically the most productive parts of the Adriatic Sea (Morović et al., 2004). These conditions seem to favour lower fecundity, larger average sizes of reproductive outputs and precocity of sexual maturation in this species compared to some other areas in the Mediterranean Sea. Moreover, the Adriatic Sea is a warm sea, even in the deepest parts temperatures are never bellow $11.5^{\circ} \mathrm{C}$ (Buljan and Zore-Armanda, 1971), and it has been previously indicated that higher average temperatures cause precocity in sexual development and a longer duration of the reproduction period (Ezzeddine-Najai, 1997; Silva et al., 2004).

The observed decrease in the number of oocytes per gram of ovary with the increase in the ovary weight can be explained by the antagonistic effect of a simultaneous increase in the volume of yolk in the oocytes and their degeneration (Boyle and Chevis, 1992; Grubert and Wadley, 2000). Spermatangia were found in a very small number of females, and have also been reported by other authors (Mangold, 1983; Ezzeddine-Najai, 1997; Silva et al., 2004). As no significant differences in the sex ratio were observed during the reproduction period, mating probably does not take place long before spawning and both male and female mature individuals migrate to areas that are not accessible to trawl nets. Reproductive migrations of E. moschata and some other eledonids have been proposed (Mangold-Wirz, 1963; Mangold, 1983; Perez and Haimovici, 1991; Perez et al., 1997; Önsoy and Salman, 2004), which could also explain the lack of spent stages in the samples.

The most intensive reproductive activity of the musky octopus in the Adriatic Sea occurs in winter and early spring. The highest percentages of mature males and females are in February and April respectively, which indicates the earlier maturation of males, and it has been shown for many cephalopod species, as well as for a variety of marine species without a social structure (Stergiou et al., 1996). E. moschata in the Adriatic Sea has an extended spawning season that starts in autumn and ends in spring. The consequence of this spawning pattern is the existence of several "microcohorts" of recruits throughout the year (Krstulović Šifner, 2004). Ezzeddine-Najai (1997) found that the reproductive season of E. moschata in Tunisian waters lasts from October to June (July). In the Gulf of Cádiz the major spawning peak was found between February and May, with one minor peak in autumn (Silva et al., 2004). Studies in the western Mediterranean showed that E. moschata reproduces between January and June with the highest number of mature individuals in March and April (Mangold-Wirz 1963; Mangold 1983), while in the eastern Mediterranean the reproductive season extends from November to July with two peaks (Akyol et al., 2007). In all the studied areas, an extensive reproductive period was observed. Minor seasonal differences in the spawning peaks are a result of the different environmental variables, as the life processes of cephalopods, including the initiation and duration of the reproductive season, are strongly affected by environmental factors, primarily temperature (Van Heukelem, 1979; Mangold, 1983). 


\section{AKNOWLEDGEMENTS}

We express our gratitude to all fishermen and the technical crew who participated in the collection of biological data. We wish to thank Mr. Igor Isajlović for his technical assistance in preparing the figures, and two anonymous reviewers who helped us improve the manuscript. This study was supported by the Scientific Research Program of the Ministry of Science, Education and Sports, Republic of Croatia.

\section{REFERENCES}

Akyol, O., H. Şen and H.T. Kinacigil. - 2007. Reproductive biology of Eledone moschata (Cephalopoda: Octopodidae) in the Aegean Sea (Izmir Bay, Turkey). J. Mar. Biol. Ass., 87: 967-970.

Belcari, P. and M. Sbrana. - 1999. Eledone moschata. In: G. Relini, J.A. Bertrand and A. Zamboni (eds.), Synthesis of the knowledge on bottom fishery resources in Central Mediterranean (Italy and Corsica). Biol. Mar. Medit., 6(Suppl. 1): 737-746.

Belcari, P., G. Tserpes, M. Gonzalez, E. Lefkaditou, B. Marčeta, G. Piccinetti Manfrin, and A. Souplet. - 2002. Distribution and abundance of Eledone cirrhosa (Lamarck, 1798) and Eledone moschata (Lamarck, 1798) (Cephalopoda: Octopoda) in the Mediterranean Sea. Sci. Mar., 66(Suppl. 2): 143-155.

Boletzky, Sv. - 1975. Le développement d'Eledone moschata (Mollusca, Cephalopoda) élevée au laboratoire. Bull. Soc. Zool. Fr. 100: 361-367.

Boyle, P.R. and D. Chevis. - 1992. Egg development in the Eledone cirrhosa. J. Zool., 227: 623-638.

Boyle, P.R. and H.I. Daly. - 2000. Fecundity and spawning in a deep-water cirromorph octopus. Mar. Biol., 137: 317-324.

Buljan, M. and M. Zore-Armanda. - 1971. Osnovi oceanografije i pomorske meteorologije. Institut za oceanografiju i ribarstvo, Split.

Casali, P., G. Manfrin Piccinetti and S. Soro. - 1998. Distribuzione di cephalopodi in alto e medio Adriatico. Biol. Mar. Medit. 5(2): 307-317.

Ezzeddine-Najai, S. - 1997. Sexual maturation in Eledone moschata (Cephalopoda, Octopoda) from the gulf of Gabes (Tunisia, eastern Mediterranean). Vie Milieu, 47(1): 69-76.

Grubert, M.A. and V.A. Wadley. - 2000. Sexual maturity and fecundity of Octopus maorum in Southeast Tasmania. Bull. Mar. Sci., 66(1): 131-142.

Krstulović Sifner, S. - 2004. Population dynamics of the Musky octopus, Eledone moschata (Lamarck, 1798), in the Adriatic Sea. Ph. D. thesis, Univ. Zagreb.

Krstulović Šifner, S., V. Dadić and N. Vrgoč. - 2004. GIS presentation of distribution of two Eledonid species in the Adriatic Sea. In: D. Kereković (ed.), GIS in research and practice, pp. 124131. Hrvatski Informatički Zbor, Zagreb.

Krstulović Šifner, S., E. Lefkaditou, N. Ungaro, L. Ceriola, K. Osmani, S. Kavadas and N. Vrgoč. - 2005. Composition and distribution of the Cephalopod fauna in the Eastern Adriatic and Eastern Ionian Sea. Isr. J. Zool., 51: 315-330.

Laptikhovsky, V.V. - 1999. Fecundity and reproductive strategy of three species of octopods from the Northwest Bering Sea. Russ. J. Mar. Biol., 25(4): 342-346.

Lefkaditou, E., A. Siapatis and C. Papaconstantinou. - 1998. Seasonal and spatial changes in the abundance and distribution of Eledone moschata (Cephalopoda: Octopoda), in the South Aegean Sea (Eastern Mediterranean). ICES CM, Copenhagen.
Lefkaditou, E., P. Leondarakis, P.C. Papaconstantinou and A. Tsangridis. - 2001. Eledonids exploited in the Thracian Sea: preliminary analysis of stock structure based on trawlers landings. Rapp. Comm. Int. Mer Médit., 36: 294-294.

Manfrin-Piccinetti, G. and M. Rizzoli. - 1984. Data obtained during the Pipeta expeditions, on the biology of Eledone moschata (Lam.) in the Adriatic. Fao Fish. Rep., 290: 139-141.

Mangold, K. - 1983. Eledone moschata. In: P.R. Boyle (ed.), Cephalopod life cycles. Vol 1, pp. 387-400, Academic Press, London.

Mangold-Wirz, K. - 1963. Biologie des Cephalopods bentiques et nectonique de la Mer Catalane. Vie Milieu, 13: 83-91.

Mangold-Wirz, K. and R. Boucher-Rodoni. - 1973. Nutrition et croissance de trois Octopodidés méditerranéens. Etude préliminaire. Rapp. Comm. int. Mer Médit., 21(10): 789-791.

Morović, M., B. Grbec and I. Marasović. - 2004. Changed patterns of remotely sensed chlorophyll a in the Adriatic - Influence of meteorological conditions. Int. J. Biodiversity Oceanol. Conserv., 68(2): 405-410.

Önsoy, B. and A. Salman. - 2004. Reproduction Patterns of the Mediterranean endemic, Eledone moschata (Lamarck, 1798) (Octopoda: Cephalopoda) in the Eastern Mediterranean. Turk. J. Aquat. Life, 2(2): 55-60.

Perez, J.A.A. and M. Haimovici. - 1991. Sexual maturation and reproductive cycle of Eledone massyae, Voss 1964 (Cephalopoda: Octopodidae) in Southern Brazil. Bull. Mar. Sci., 49(1-2): 270-279.

Perez, J.A.A., M. Haimovici and R.A. Santos. - 1997. Observations on the reproductive biology of the octopod Eledone gaucha Haimovici, 1988, in the southern Brazil. Amer. Malac. Bull., 14(1): 81-84.

Piccinetti, C. and S. Jukić. - 1988. Data on the demersal resources of the upper and middle Adriatic. FAO Fish. Rep., 394: 172-173.

Pipitone, C., F. Badalamenti, G. D'Anna and B. Patti. - 2000. Fish biomass increase after a four-year trawl ban in the Gulf of Castellammare (NW Sicily, Mediterranean Sea). Fish. Res., 48(1): 23-30.

Quetglas, A., A. Carbonell and P. Sanchez. - 2000. Demersal continental shelf and upper slope cephalopod assemblages from the Balearic Sea (NW Mediterranean). Biological aspects of some deep-sea species. Estuar. Coast. Shelf Sci., 50(6): 739-749.

Rocha, F., A. Guerra and A.F. Gonzalez. - 2001. A review of reproductive strategies in cephalopods. Biol. Rev., 76: 291-304.

Roper, C.F.E., M.J. Sweeney and C.E. Nauen. - 1984. FAO species catalogue. Vol. 3. Cephalopods of the world. An annotated and illustrated catalogue of species of interest to fisheries. FAO Fish. Synop. No. 125, 3: 1-277.

Salman, A., T. Katagan and A.C. Gucu. - 2000. The distribution and fishing of two Mediterranean Eledone spp. (Octopoda: Cephalopoda) in the Aegean Sea. Turk. J. Zool., 24: 165-171.

Şen, H. - 2007. Food preferences of Eledone moschata Lamarck, 1799 (Cephalopoda: Octopodidae) in Captive Conditions. Int. J. Nat. Eng. Sci.,1(2): 29-31.

Silva, L., F. Ramos and I. Sobrino. - 2004. Reproductive biology of Eledone moschata (Cephalopoda: Octopodidae) in the Gulf of Cádiz (south-western Spain, ICES Division IXa). J. Mar. Biol. Ass. U.K., 84: 1221-1226.

Soro, S. and G. Piccinetti Manfrin. - 1989. Biologia e pesca di Cefalopodi in Adriatico. Nova Thalassia, 10(1): 493-498.

Stergiou, K.I., P. Economidis and A. Sinis. - 1996. Sex ratio, spawning season and size at maturity of red bandfish in the western Aegean Sea. J. Fish Biol., 49: 561-572.

Van Heukelem, W.F. - 1979. Environmental control of reproduction and life span in Octopus: An hypothesis. In: S.E. Stancyk (ed.), Reproductive Ecology of Marine Invertebrates, pp. 123133, University of South Carolina Press, Columbia.

Scient. ed.: P. Sánchez.

Received March 3, 2008. Accepted October 21, 2008.

Published online April 6, 2009. 